\title{
Contract Principal Investigator
}

National Cancer Institute

\section{Source}

National Cancer Institute. Contract Principal Investigator. NCI Thesaurus. Code C51817.

A scientist or health care professional that has a financial agreement, as outlined in a binding statement of work, with the sponsor to bear full and ultimate responsibility for the scientific, administrative, ethical, legal, technical, and fiscal aspects of the study, and for day-to-day management of the scientific project, as well as for documenting and reporting its results. 